\title{
Retraction
}

\section{Retracted: Interaction of TMPyP4, TMPyP3, and TMPyP2 with Intramolecular G-Quadruplex Formed by Promoter Region of Bcl2 and KRAS NHPPE}

\author{
ISRN Biophysics \\ Received 15 March 2013; Accepted 15 March 2013 \\ Copyright (C) 2013 ISRN Biophysics. This is an open access article distributed under the Creative Commons Attribution License, \\ which permits unrestricted use, distribution, and reproduction in any medium, provided the original work is properly cited.
}

This article has been retracted upon the authors' request, as they have incorporated the studies of two oncogene promoter regions which form G-quadruplex complex (i.e., Bcl2 and KRAS), but the DNA considered for the studies was not from these regions. The DNA samples got mixed up, and they are from other regions of oncogene promoter. The complete ESIMS (mass data) and the ITC (microcalorimetry data) were wrong. Since the mistake occurred at the fundamental level (i.e., at the DNA itself), the whole experiment gave wrong data. Additionally, the article was submitted for publication by the author Narayana Nagesh without the knowledge and approval of the other author Arumugam Ganesh Kumar [1].

\section{References}

[1] N. Nagesh and A. Ganesh Kumar, "Interaction of TMPyP4, TMPyP3, and TMPyP2 with intramolecular G-quadruplex formed by promoter region of $\mathrm{Bcl} 2$ and KRAS NHPPE," ISRN Biophysics, vol. 2012, Article ID 786596, 12 pages, 2012. 